\title{
PERBANDINGAN HASIL \\ TANAMAN PAKCHOY (Brassica rapa) \\ DENGAN PEMBERIAN \\ PUPUK ORGANIK YANG BERBEDA
}

\author{
SIRLYANA SIRLYANA ${ }^{* 1}$, SURTINAH SURTINAH ${ }^{2}$ \\ ${ }^{1}$ Prodi Teknik Industri Sekolah Tinggi Teknologi Dumai \\ J1. Takari No. 94. Dumai \\ ${ }^{2}$ Prodi Agroteknologi Fakultas Pertanian Universitas Lancang Kuning \\ Jl. Yos Sudarso, Km. 8 Rumai, Pekanbaru \\ "E-mail : sirlyana12345@gmail.com
}

\begin{abstract}
ABSTRAK
Tujuan penelitian ini adalah untuk mendapatkan alternative pengganti pupuk kandang dalam budidaya tanaman Pakchoy. Penelitian percobaan dilakukan dengan menggunakan dua perlakuan yaitu pupuk kandang dan kompos tanaman jagung manis, perlakuan diulang $10 \mathrm{kali}$, uji statistic yang digunakan adalah uji-t tidak berpasangan. Untuk mencapai tujuan penelitian dilakukan pengamatan terhadap pertumbuhan dan hasil pakchoy. Hasil penelitian yang direkomendasikan adalah kompos tanaman jagung manis dapat digunakan sebagai pengganti pupuk kandang dalam budiday pakchoy.
\end{abstract}

Kata kunci: Alternatif, Kompos , Pakchoy, pupuk kandang

\section{ABSTRACT}

The purpose of this study was to obtain an alternative substitute for manure in the cultivation of Pakchoy plants. The experimental study was conducted using two treatments, namely manure and compost of sweet corn plants, the treatment was repeated 10 times, the statistical test used was the unpaired t-test. To achieve the objectives of the study, observations were made on the growth and yield of Pakchoy. The recommended research results are that sweet corn compost can be used as a substitute for manure in Pakchoy's culture.

Keywords: Alternative, Kompos, Pakchoy, manure

Diterima: 17 Februari 2019, disetujui 12 April 2019

\section{PENDAHULUAN}

Pakchoy (Brassica rapa) yang membutuhkan media tanam yang merupakan sayuran yang tidak asing lagi subur dalam membudidayakannya. Tanah bagi masyarakat Pekanbaru, dan Pakchoy yang subur di Pekanbaru sulit ditemui, merupakan sayur yang memiliki sehingga untuk menjadikan tanah menjadi kandungan antioksidan dan serat yang subur biasanya digunakan pupuk organic tinggi, dan sangat dibutuhkan untuk yang berupa pupuk kandang. kesehatan. Pakchoy merupakan tanaman Ketersediaan pupuk kandang di Pekanbaru 
sangat terbatas, sehingga perlu dicarikan alternative pengganti pupuk kandang untuk diberikan ke media tanam.

Tanaman jagung manis merupakan tanaman yang sudah berkembang di Pekanbaru, sisa dari hasil budidaya adalah sampah, dan sampah jagung manis ini diolah dijadikan kompos. Surtinah (2013) melaporkan bahwa sisa tanaman jagung manis yang dijadikan kompos mengadung $\mathrm{K} 7,2 \%, \mathrm{~N} 1,05 \%, \mathrm{P}_{2} \mathrm{O}_{5} 1.01 \%, \mathrm{~K}_{2} \mathrm{O}$ $0.18 \%, \mathrm{CaO} 1.98 \%, \mathrm{MgO} 0.53 \%, \mathrm{Fe}$ $0.19 \%$, $\mathrm{C}$ organic $10.5 \%$, dan $\mathrm{C} / \mathrm{N}$ rasio 9.97. Kompos inilah yang diharapkan sebagai salah satu alternative yang dapat menggantikan pupuk kandang.

Prasetyo dan Sinaga ( 2017) melaporkan bahwa perlakuan jenis pupuk organic yang dikombinasikan dengan dosis pupuk organic memberikan beda nyata terhadap pertumbuhan dan produksi umbi per plot. Pada penelitian yang lain Sayekti, Prayitno, dan Indradewa (2016) melaporkan bahwa pupuk kandang dan kompos yang diberikan sebagai perlakuan pada tanaman kangkung akuaponik dapat meningkatkan pertumbuhan dan produksi dibandingkan dengan tanpa pemberian perlakuan tersebut. Media tanam tanah pasir yang diberi perlakuan $150 \mathrm{~kg} \mathrm{~N}$ hektar ${ }^{-1}$ dapat meningkatkan pertumbuhan dan produksi terung (Waskito, Aini, dan Koesriharti, 2017).

Pupuk kandang sapi yang diberikan pada budidaya cabai rawit dapat meningkatkan pertumbuhan vegetative dan pertumbuhan genetatif, pada lahan rawa lebak, dosis yang digunakan adalah 20 ton hektar ${ }^{-1}$ (Hafizah, dan Mukarramah, 2017). Jenis pupuk kandang yang diberikan pada tanaman cabai merah dapat meningkatkan hasil, dosis pukan sapi yang terbaik adalah 90 ton hektar ${ }^{-1}$ dan mendapatkan hasil sebesar 302,58 gram tanaman ${ }^{-1}$ (Prasetyo, 2014).

Arifah (2013) melaporkan kombinasi takaran dan macam pupuk organic berpengaruh terhadap seluruh parameter pengamatan, dan hasil yang tertinggi diperlihatkan oleh perlakuan pupuk kandang ayam 10 ton hektar ${ }^{-1}$. Tanaman bawang merah yang diberi perlakuan pupuk kandang sapi dengan takaran 30 ton hektar ${ }^{-1}$ menghasilkan berat kering tanaman sebesar 15,37 gram plot $^{-1}$, dan menumbang C-organik ke dalam media tanam $2,44 \%$, P total $56,75 \mathrm{mg}$ dalam 100 gram, $\mathrm{P}$ tersedia sebesar 55,07 ppm, $\mathrm{P}$ pada jaringan tanaman $0,096 \%, \mathrm{P}$ dalam jaringan umbi $0,090 \%$, dan serapan P 3,07 gram tanaman ${ }^{-1}$. Pupuk kandang yang diberikan sampai dosis 30 ton hektar ${ }^{1}$ menunjukkan kecenderungan garis linier pada seluruh parameter pengamatan (Amijaya, Pata'dunga, dan Thaha, 2015).

Tanaman nyamplung yang ditanam pada tanah PMK yang diberi pupuk kandang sapi menhasilkan tumbuh dan berkembangnya organ vegetatife tanaman dibandingkan tanpa pemberian pupuk kandang sapi (Raiwani, Burhanudin, dan Darwati, 2016). Pemberian pupuk kandang sapi 5 ton hektar ${ }^{-1}$ dengan kombinasi tumpangsari barisan ganda memperlihatkan pertumbuhan dan hasil panen yang terbaik, begitu juga ditinjau dari keuntungan yang diperoleh ditinjau dari sudut ekonomi (Evanita, Widaryanto, dan Heddy, 2014). Tujuan penelitian adalah untuk mendapatkan alternative pengganti pupuk kandang yang menghasilkan produksi tanaman yang sama baiknya dengan yang dihasilkan oleh tanaman yang menggunakan pupuk kandang. 


\section{METODE PENELITIAN}

Penelitian ini dilaksanakan di Jalan Sumatera Pekanbaru dengan ketinggian tempat 10 meter dari permukaan laut. Jenis tanah PMK, Topografi datar. Pelaksanaan eksperimen di lapangan dilakukan mulai bulan Nopember sampai Desember tahun 2017.

Bahan yang digunakan adalah benih Pakchoy, pupuk kandang sapi, kompos sisa tanaman jagung manis, pupuk NPK, dan polybag ukuran 18 x 25 $\mathrm{cm}$. dan alat alat yang digunakan adalah alat ukur, peralatan budidaya tanaman, alat tulis, timbangan, dan alat penyiram tanaman.

Rancangan perlakuan adalah A : media tanam diberi pukan dan tanah top soil PMK dengan perbandingan 3:1 ( 3 bagian tanah dan 1 bagian pupuk kandang sapi). B: media tanam diberi kompos sisa tanaman jagung manis dengan perbandingan 3:1 (3 bagian tanah dan 1 bagian kompos). Rancangan perlakuan yang digunakan adalah rancangan acak lengkap dan seluruh perlakuan diulang sebanyak 10 kali. Uji statistic yang digunakan adalah uji t-tidak berpasangan.

Median tanam yang digunakan terdiri dari tanah top soil PMK yang dicampur dengan pupuk kandang dan

\section{HASIL DAN PEMBAHASAN}

Data yang diperoleh pada penelitian ini terhadap tanaman pakchoy menunjukkan pertumbuhan dan produksi yang berbeda tidak nyata untuk semua kompos sesuai dengan perlakuan yang ditetapkan. Media tanam yang dimasukkan ke dalam polybag dicampur terlebih dahulu dengan pupuk kandang dan kompos, dan dimasukkan ke polybag dengan berat masing-masing $1 \mathrm{~kg}$.

Bibit pakchoy yang sudah disemai, dipindah tanamkan pada umur 4 hari setelah semai, bibit yang sudah berada di polybag diberi naungan pelepah daun pisang untuk melindungi bibit dari curah hujan. Pada umur seminggu setelah semai naungan dibuka dan tanaman pakchoy dipelihara dengan diberi pupuk NPK (16:16:16) sebanyak 2 gram per tanaman, dan pemupukan kedua diberikan pada tanaman pakchoy yang berumur 3 minggu dengan takaran 2 gram per tanaman.

Penyiraman dilakukan pagi dan sore, air yang diberikan sebanyak 1 liter per tanaman. Penyiangan gulma dilakukan secara manual, dan tidak dilakukan pencegahan hama dan penyakit. Panen dilakukan pada umur 28 hari setelah semai.

Pengamatan dilakukan terhadap tinggi tanaman, jumlah daun, panjang daun, lebar daun, berat segar tanaman, berat konsumsi, dan panjang akar. Pengamatan dilakukan pada saat panen.

parameter pengamtan. Rekap hasil pengamatn dan hasil uji-t dapat dilihat pada Tabel berikut ini.

Tabel 1. Pengamatan terhadap seluruh parameter pertumbuhan dan produksi pakchoy dengan pemberian pupuk organic yang berbeda 


\begin{tabular}{clcccc}
\hline No & \multicolumn{1}{c}{ Pengamatan } & Rata-rata P & Rata-rata K & $\mathrm{T}_{\text {hitung }}$ & $\mathrm{T}_{\text {tabel 5\% }}$ \\
\hline 1 & Tinggi tanaman (cm) & 16.84 & 17.35 & 0.71 & 2.262 \\
2 & Jumlah daun (helai) & 12.27 & 12.93 & 1.34 & 2.262 \\
3 & Panjang daun (cm) & 14.62 & 14.67 & 0.12 & 2.262 \\
4 & Lebar daun (cm) & 06.79 & 06.95 & 0.55 & 2.262 \\
5 & B.segar tanaman (g) & 36.77 & 38.97 & 1.55 & 2.262 \\
6 & Berat dikonsumsi (g) & 34.63 & 36.87 & 1.43 & 2.262 \\
7 & Panjang akar (cm) & 12.03 & 12.39 & 0.34 & 2.262 \\
\hline
\end{tabular}

Hasil penelitian yang menguji dua jenis pupuk organic yaitu pupuk kandang sapi dan kompos sisa tanaman jagung manis menghasilkan pertumbuhan dan produksi pakchoy yang berbeda tidak nyata. Artinya bahwa antara pupuk kandang dan kompos sisa tanaman jagung manis memberikan manfaat yang sama apabila digunakan untuk perbaikan sifat fisik dan kimia tanah sebagai media tanam.

Kandungan unsur hara dan bahan organic yang ada pada pupuk kandang sangat bermanfaat untuk menambah unsur hara pada tanah PMK. Bahan organic yang terkandung di dalam pupuk kandang berperan sebagaai penggembur tanah dan menjaga kelembaban tanah, dengan adanya bahan organic di dalam tanah maka aerasi, porositas tanah akan tetap terjaga yang menyebabkan ketersediaan oksigen di zona perakaran terjamin. Ketersediaan oksigen yang tersedia di zona perakaran akan melancarkan respirasi akar yang akan menghasilkan energy yang akan digunakan untuk pertumbuhan dan perkembangan tanaman. Fauzi, Putra,dan Ambarwati, (2013) melaporkan bahwa tanaman selada yang media tanamnya diberi tekanan aerasi yang semakin tinggi dan konsentrasi oksigen terlarutnya yang semakin tinggi menunjukkan pertumbuhan dan produksi selada yang semakin meningkat. Surtinah (2016) menginformasikan bahwa dengan adanya oksigen pada media tanam dapat meningkatkan pertumbuhan tanaman pakchoy.

Choiron, Jayus, dan Swasono (2013) melaporkan bahwa berat segar dan hasil epiglukan meningkat dengan semakin tinggi keberadaan $\mathrm{O}_{2}$, dan produksi epiglukan terbaik adalah dengan perlakuan oksigenasi sebesar 2,01 $\mathrm{g} \mathrm{liter}^{-1}$.

Pupuk kandang dan kompos yang diberikan ke media tanam akan memperbaiki kondisi fisik tanah, dan kimia tanah. Hara yang terkandung di dalam pupuk kandang dan kompos sisa tanaman jagung manis minimal menambah hara yang diperlukan tanaman. Bahan organic yang terkandung dalam pupuk organic selain memperbaiki kondisi fisik tanah, juga dapat mempertahankan kelembaban tanah, sehingga keberadaan air di dalam tanah akan dimanfaatkan oleh akar tanaman untuk menyediakan kebutuhan tanaman dalam melaksanakan proses fotosintesis yang hasilnya berupa fotosintat yang menjadi bahan makanan untuk tanaman. Kelembaban tanah juga dapat menurunkan suhu tanah menjadi lebih stabil sehingga kecepatan respirasi akar akan dapat ditekan menjadi normal. Media tanam yang terdiri dari campuran tanah, pasir, dan serbuk gergaji dengan tambahan $\mathrm{N}$ $250 \mathrm{~kg}$ per hektar menghasilkan berat buah per tanaman, berat per buah, diameter buah dan panjang buah terong menjadi meningkat (Waskito, Aini, dan Koesriharti, 2017). 
Pertumbuhan dan hasil pakchoy pada kedua media tanam berbeda tidak nyata yang dapat dijelaskan bahwa kompos sisa tanaman jagung manis dapat menggantikan pupuk kandang dalam budidaya tanaman sayur. Novizan (2005) bahan organik yang diberikan ke media tanam berperan sebagai penambah unsur hara, yang berfungsi untuk memperbaiki

\section{KESIMPULAN}

Kesimpulan yang diperoleh dari penelitian ini adalah pupuk kandang sapi dan kompos sisa tanaman jagung manis dapat digunakan untuk budidaya tanaman

\section{UCAPAN TERIMA KASIH}

Terimakasih kepada editor Jurnal Ilmiah Pertanian yang telah memberikan kesempatan kepada penulis untuk mempublikasikan hasil penelitian ini, dan

\section{DAFTAR PUSTAKA}

Akbar, Y., dan Yuliani, P., 2017. Respon Pertumbuhan dan Hasil Tanaman Bawang Merah (Alium ascalonikum, L) pada Beberapa Media Tanam. Jurnal Pertanian UNSB, Vol.1(2): 44-49.

Amijaya, M., Pata'dunga, Y., dan Thaha, A.R., 2015. Pengaruh Pupuk Kandang Sapi terhadap Serapan Posfor dan Hasil Tanaman Bawang Merah (Allium ascalonicum,L) Varietas Lembah Palu di Entisol Sidera. e - Jurnal Agroteknis, Vol. 3(2):187-197.

Arifah, S.M., 2013. Aplikasi Macam Dan Dosis Pupuk Kandang Pada Tanaman Kentang. Jurnal Gamma, Vol. 8(2):80-85. sifat fisik tanah, dan menambah mikroorganisma tanah. Bahan organik tanah berperan dalam menjaga kelembaban tanah, sehingga suhu tanah menjadi lebih stabil dan kehidupan mikroorganisma tanah menjadi lebih baik, akibatnya bila ada penambahan pupuk anorganik maka pupuk tersebut akan lebih bermanfaat untuk pertumbuhan tanaman.

pakchoy. Kompos sisa tanaman jagung manis dapat menjadi alternative pengganti pupuk kandang sapi dalam budidaya tanaman pakchoy.

terimakasih juga diucapkan kepada semua pihak yang sudah membantu penyelesaian penelitian ini.

Choiron, M., Jayus, dan Suwasono, S., 2013. Pengaruh Ketersediaan Oksigen Pada Produksi Epiglukan Oleh Epicoccum nigrum Menggunakan Media Molases. Jurnal Agrointek, Vol.7(1): 11-20.

Evanita, E., Widaryanto, E., dan Heddy, Y.B.S., Pengaruh Pupuk Kandang Sapi Pada Pertumbuhan dan Hasil Tanaman Terong (Solanum melongena L) Pada Pola Tanam Tumpangsari dengan Rumput Gajah (Penisetum purpureum) Tanaman Pertama. Jurnal Produksi Tanaman, Vol 2(7): 533-541.

Hafizah, N., dan Mukarramah, R., 2017. Aplikasi Pupuk Kandang Kotoran Sapi Pada Pertumbuhan dan Hasil Tanaman Cabai Rawit (Capsicum fristescens, L) di Lahan Rawa Lebak. J. Ziraa'ah, Vol. 42(1):1-7. 
Nabu, M., dan Taolin, R.I.C.O., 2016. Pengaruh Jenis Pupuk Kandang dan Komposisi Media Tanam Terhadap Pertumbuhan Bibit Sengon Laut (Parasiathes falcataria, L). Jurnal Savana Candana, Vol. 1(2): 59-62.

Novizan, 2005. Petunjuk Pemupukan yang Efektif pada Pupuk Kandang, cetakan pertama. AgroMedia Pustaka. Jakarta.Journal of Agro Science. Vol. 2(2): 125-132.

Prasetyo, R., 2014. Pemanfaatan Berbagai Sumber Pupuk Kandang sebagai Sumber N dalam Budidaya Cabai Merah (Capsicum annum, L) di Tanah Berpasir. Planta Tropika

Prasetyo, H. A., dan Sinaga, L.L., 2017. Respon Pemberian Jenis dan Dosis Pupuk Organik Terhadap Pertumbuhan dan Produksi Bawang Merah (Allium ascalonicum, L). Jurnal Agroteknosains, Vol. 01(01): 69-77.

Raiwani, R., Burhanuddin, dan Darwati, H., 2016. Pengaruh Pupuk Organik Kotoran Sapi Terhadap Pertumbuhan Nyamplung (Calophyllum inophyllum, Linn)
Pada Tanah Ultisol. Jurnal Hutan Lestari, Vol. 4(4): 596-604.

Sayekti, R.S., Prayitno, D., dan Indradewa, D., 2016. Pengaruh Pemanfaatan Pupuk Kandang dan Kompos terhadap Pertumbuhan Kangkung (Ipomea reptans) dan Lele Dumbo (Clarias gariepinus) pada Sistem Akuaponik. Jurnal Teknologi Lingkungan, Vol.17(2):106-117.

Surtinah, S. (2013). Pengujian Kandungan Unsur Hara Dalam Kompos Yang Berasal Dari Serasah Tanaman Jagung Manis (Zea mays saccharata). Jurnal Ilmiah Pertanian, 11(1), 11-17.

Surtinah, 2016. Penambahan Oksigen Pada Media Tanam Hidroponik Terhadap Pertumbuhan Pakchoy (Brassica rapa). Jurnal Bibiet, Vol. 1(1):27-35.

Waskito, K., Aini, N., dan Koesrihati, 2017. Pengaruh Komposisi Media Tanam Dan Pupuk Nitrogen Terhadap Pertumbuhan dan Hasil Tanaman Terong (Solanum melongena L.) Jurnal Produksi Tanaman, Vol. 5(10): 1586-1593. 